\title{
RAINFALL AND DEFORESTATION IN THE MUNICIPALITY OF COLÍDER, SOUTHERN AMAZON
}

\author{
ISABELLE BONINI ${ }^{1}$, CLEVERSON RODRIGUES ${ }^{2}$, RIVANILDO DALLACORT ${ }^{3}$, BEN HUR \\ MARIMON JUNIOR ${ }^{1}$, MARCO ANTÔNIO CAMILLO CARVALHO ${ }^{2}$ \\ ${ }^{1}$ Universidade do Estado de Mato Grosso (UNEMAT), Laboratório de Ecologia Vegetal, Nova Xavantina, \\ MT, Brazil \\ ${ }^{2}$ UNEMAT, Departamento de Agronomia, Alta Floresta, MT, Brazil \\ ${ }^{3}$ UNEMAT, Departamento de Agronomia, Tangará da Serra, MT, Brazil
}

isabelle_biologa@hotmail.com, cleverson-ro@hotmail.com,rivanildo@unemat.br,bhmjunior@gmail.com, marcocarvalho@unemat.br

Received June 2013 - Accepted December 2013

\begin{abstract}
Deforestation may have effects on the hydrological cycle, directly reflecting in the rainfall rates. Therefore, studies pointing out evidence of climate changes caused by deforestation are extremely important, because they help understanding the way how these changes are related to forms of using and occupying the territory, as well as to the way how information obtained can to be useful for mitigating their effects. In this context, this paper aimed to analyze rainfall variations occurring in the municipality of Colíder, Mato Grosso, southern Amazon,Brazil, within a temporal scale of 28 years (daily data), correlating them to the regional and local deforestation patterns by determining Spearman's $\rho$ coefficient. Annual rainfall presented a large variation, with a minimum of $1,296 \mathrm{~mm}$ in 1987 and a maximum of 2,492.8 $\mathrm{mm}$ in 1990. The rainy season was concentrated between October and April, and the driest period was within June and August. Spearman's coefficient pointed out negative correlations between regional and local deforestation and local rainfall, showing that the larger the deforested area, the lower the rainfall rate observed.

Keywords: Rainfall variability, Gamma probability, Vegetation removal, Arc of deforestation.

RESUMO: PRECIPITAÇÃO PLUVIOMÉTRICA E DESMATAMENTO NO MUNICÍPIO DE COLÍDER, SUL DA AMAZÔNIA

A destruição das florestas pode ter efeitos no ciclo hidrológico, refletindo diretamente nas taxas de precipitação. Desta maneira, estudos que apontem indícios de alterações climáticas ocasionadas pelo desmatamento são extremamente importantes, pois facilitam a compreensão de como estas mudanças estão relacionadas às formas de uso e ocupação do território e de que modo as informações obtidas serão úteis na mitigação dessas mudanças. Neste contexto, o objetivo deste artigo foi analisar as variações pluviométricas ocorridas no município de Colíder (MT), sul da Amazônia, em uma escala temporal de 28 anos (dados diários), correlacionando-as aos padrões regionais e locais de desmatamento por meio da determinação do coeficiente $\rho$ de Spearman. A precipitação anual apresentou grande variação, com mínima de 1.296 mm em 1987, e máxima de 2.492,8 mm em 1990. O período chuvoso concentrou-se entre outubro e abril, e o período mais seco foi entre junho e agosto. O coeficiente de Spearman apontou correlações negativas entre o desmatamento regional e local com a precipitação local, evidenciando que quanto maior for a área desmatada, menor será a taxa pluviométrica observada. Palavras-chave: Variabilidade pluviométrica, Probabilidade Gama, Supressão da vegetação, Arco do desmatamento.
\end{abstract}




\section{INTRODUCTION}

The increase in rainfall seasonality in some tropical regions is a hotly debated issue in the domain of global climate changes. More intense and frequent droughts in the Amazon, for instance, may be related to deforestation (Aragão et al. 2012) or to increase in carbon emissions and global warming (e.g. Lewis et al. 2011), although the subject is still quite controversial. Intensification in the dry season when compared to the rainy season in Neotropical countries constitutes itself as a major environmental concern nowadays, since there may be a direct relation of this process to land misuse (Negri et al. 2004).

For these reasons, climate changes should become an important analytical element for the organization and the territorial and environmental planning, due to the high interference, impact, and repercussion degree in time and space (Costa et al. 2012). Studies pointing out evidence of climate changes caused by deforestation are vital, because they help understanding the way how these changes are related to forms of using and occupying the territory, as well as to the way how scientific information connect themselves in order to be useful for mitigating their effects on land use, although it's difficult to exactly determine what are the connections between these factors and climate.

Rainfall is the meteorological variable which directly influences on water balance, and it can determine the excess or shortage of water in the soil of a given region (Liberato and Brito, 2010). Besides being essential to the vital activities, it's one of the most important control agents of the hydrologic cycle and the ecological and geographical conditions of landscapes (Rosa et al. 2007), especially with regard to the native vegetation.

Total monthly and annual rainfall variations reflect the behavior of regional atmospheric circulation throughout the year and they are inter-related to geographic factors (local or regional). Such variations are intrinsic reflexes of the dynamics of atmosphere itself, in the face of which many human interventions can cause severe environmental changes (Buckeridge, 2008).

The relative amounts of rainfall, the volume, the seasonal or daily regimens, the temporal distribution and intensities of individual rainfalls are characteristics which directly or indirectly affect the environmental conditions (Sousa et al. 2006). From this climatic viewpoint, the state of Mato Grosso presents important environmental peculiarities, such as the wide variation in vegetation and soil types, the topographic complexity, and the geographic positioning involving three major Brazilian biomes with different rainfall distribution patterns (Marcuzzo et al. 2010). In this case, the most significant annual rainfall volume was concentrated on the southern Amazon (northern Mato Grosso), a region also known as the "deforestation arc", due to the advance of agricultural frontier on native vegetation.

This region has received a special attention due to its mega-diversity and the environmental services provided by their forests. Such attention is closely connected to society fears in the face of environmental changes caused by the increase of human activities all around the world (e.g. $\mathrm{CO}_{2}$ emissions). These changes have negatively affected biodiversity, decreased the production capacity of ecosystems, and changed the local climate, with direct reflexes on the average annual temperatures, rainfall rates, and occurrence of extreme weather events (Buckeridge, 2007).

These climatic phenomena are determined by a set of elements with various natures coexisting in a complex system of reciprocal and interdependent energy exchanges between the atmosphere and the Earth's surface (Correa and Galvani, 2012). The identification of such climatic components and their interactions with biotic factors (e.g. forests) may provide means for developing strategies to reduce impacts, above all in areas of great ecological interest, as it's the case of the agricultural frontier in southern Amazon. Currently, deforestation has been pointed out as one of the major causes of the regional and even global climate change, constituting itself as an important factor to be analyzed in the biosphere/atmosphere interaction (Moraes et al. 2013).

Deforestation rates in the Amazon have varied over time (Lapola et al. 2011). The historical causes of this process comprise both tax incentives and colonization projects and the recent macroeconomic scenario, involving the advancement of agricultural activities and logging (Reydon, 2011). It is likely that this fact has contributed to maximization of climate changes in the region, since forests have a direct influence on the climate, causing variations in temperature and relative air humidity (Delire et al. 2011) at different scales (Souza, 2006).

In this scenario, deforestation is the main element which causes disruptions in the regional hydrological cycle, with strong local decreases in rainfall (Aragão et al. 2012). Therefore, the rainfall consequences of the intense conversion of native forests into pastures and crops in southern Amazon may be as relevant as or more relevant than the effects caused by carbon emissions and global warming in terms of climate changes. Furthermore, the combination of both effects can generates a negative synergy in the regional rainfall distribution.

Thus, it is important to consider that the expansion of agricultural frontier in the Amazon of Mato Grosso has shown to be a powerful agent for constructing a scenario of great forest devastation, above all because of the establishment of intensive agricultural and livestock production, threatening not only the 
hydrological cycle, but also the local flora and fauna integrity. The key issue is that such landscape changes weren't combined to previous climate and/or environmental studies warning about the true risks of unplanned occupation and pointing out the need for a sustainable production (Bariou et al. 2002).

In this context, this study aimed to identify, in mesoscale, possible relations between deforestation and rainfall variations occurring in the municipality of Colíder, southern Amazon, within a period of 28 years. One intends to contribute to the knowledge basis for evaluating the impacts of land use in the Amazon climate scenario.

\section{MATERIAL AND METHODS}

The research was carried out in the municipality of Colíder, located at the Southern Amazon Depression, microregion of Colíder, northern Mato Grosso. It presents an Aw type climate, according to Köppen's classification (Ferreira, 2001), with average annual rainfall of $2,500 \mathrm{~mm}$, relative humidity ranging around 17 and $98 \%$ and an average temperature of $24^{\circ} \mathrm{C}$, with the higher temperatures of $40{ }^{\circ} \mathrm{C}$ and lowest $4^{\circ} \mathrm{C}$ (Seluchinesk, 2008; INPE, 2011a). The terrain is a part of the Northern Residual Plateau of Mato Grosso, at $300 \mathrm{~m}$ altitude. The vegetation consists of open and dense ombrophilous forest, seasonal forest, and savanna formations (Farid et al., 1992). Colíder has $3038 \mathrm{~km}^{2}$ of forested area and is located at the so-called deforestation arc, southern Amazon, and it went through an intense colonization process in the 1980s and 90 s, with conversion of the native forest into pastures and crops (Guimarães and Leme, 2002).

Rainfall data were made available by the weather bureau of the National Water Agency (ANA) in the municipality

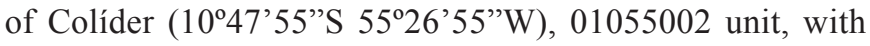
information from 1983 on.

Data concerning deforestation were obtained through information made available by the National Institute for Space Researches (INPE), using the methodology of the Estimation of Deforestation in the Amazon Project (PRODES), with data from 1989 on. For obtaining the deforestation rates, one used regional data (Amazon of Mato Grosso) from 1989 to 2011 and local data from the municipality of Colíder from 2000 to 2011. The municipality's total area is $3,038 \mathrm{~km}^{2}$, reaching $78 \%$ of the deforested area in 1999 (INPE, 2011b).

The occurrence of dry and rainy days in the municipality was analyzed within the temporal scale of 28 years, besides the monthly average within the same period, regarding as dry the days whose rainfall was $\leq 1.0 \mathrm{~mm}$ (Fietz et al. 2011a). It's noteworthy that the years 1988, 1992, and 1993 were excluded from the analysis because they had flaws concerning data collection.
One determined the different rainfall probability levels through the gamma probability density function (GPDF) and its parameters $(\alpha$ and $\beta$ ), according to the probabilistic incomplete gamma distribution model (Thom, 1958). The expression of GPDF for a $\mathrm{x}$ variable is:

$$
f(x)=\frac{1}{\beta^{\alpha} \Gamma(\alpha)} x^{a-1} e^{-x / \beta}
$$

where $\alpha$ is the shape parameter (dimensionless), $\beta$ is the scale parameter $(\mathrm{mm}), e$ is the Napierian logarithm basis, $x$ is total rainfall $(\mathrm{mm})$, and $\Gamma$ is the Gamma function symbol, defined according to the following equation:

$$
\Gamma(a+1)=\sqrt{2 \Pi a a^{a}} e^{a}\left(1+\frac{1}{12 a}+\frac{1}{288 a^{2}}-\frac{139}{5184 a^{3}}\right)
$$

One used the moments method, which consists in equalizing the sample average $(X)$ and the sample variance $\left(\mathrm{S}^{2}\right)$ to the population average and variance, generating the following equations, according to Assis et al. (1996):

$$
\begin{aligned}
& a=\frac{\bar{x}^{2}}{s^{2}} \\
& \beta=\frac{s^{2}}{\bar{x}}
\end{aligned}
$$

where $\operatorname{bar}\{\mathrm{X}\}=$ average rainfall within the period $(\mathrm{mm})$ and $\mathrm{S}^{2}=$ variance $\left(\mathrm{mm}^{2}\right)$.

GPDF is a statistical model for probability distribution which has been widely used in probability distribution studies, because this type of data set generally does not have a uniform distribution around the average value, but rather an irregular one, and, in this case, the gamma distribution best represents the probability distribution concerning rainfall (Furlan, 2009).

For checking the existence of a significant function between the variables local and regional rainfall and deforestation, one performed a polynomial regression between the annual average rainfall $(\mathrm{mm})$ and the deforested area $\left(\mathrm{km}^{2}\right)$ over time (28 years) (Zar, 1999).

For checking the possible relations between deforestation rate at the local and regional level to the annual distribution of local rainfall, one used Spearman's correlation coefficient $(\rho)$, whose formula is:

$$
\rho=1-\frac{6 \sum d_{i}^{2}}{n^{3}-n}
$$

where $n$ is the number of pairs (xi, yi) and $d_{i}=$ (xi points between the $\mathrm{x}$ values) - (yi points between the y values). Spearman's correlation coefficient varies between -1 and 1 , and the closer these extremes, the greater the association between variables. The negative correlation sign means that the variables vary in 
the opposite direction, i.e. the higher categories of a variable are associated to the lower categories of the other variable.

Whereas the more intense deforestation process took place from 1989 to 1999 , with $78 \%$ of the total area of Colíder deforested, one calculated Spearman's correlation between local rainfall and the local deforested area concerning this specific temporal scale.

Calculations were performed using the software Action 2.4 (ESTATCAMP, 1991).

\section{RESULTS AND DISCUSSION}

The annual rainfall behavior during the delimited temporal scale showed a large variation, with a minimum of $1,296 \mathrm{~mm}$ in 1987 and a maximum of 2,492.8 $\mathrm{mm}$ in 1990 . The average observed for the period was $1,868.4 \mathrm{~mm}$, with a standard deviation of $302.29 \mathrm{~mm}$. The annual rainfall distribution indicated that $52 \%$ of years had rainfall rates above average, among which $61.54 \%$ were concentrated on the first half of the observed period. In contrast, $48 \%$ of years showed rainfall below average rainfall, concentrated on the second half of the period, especially in the last eight years (Figure 1).

The regression test revealed a significant decreasing polynomial tendency in rainfall due to deforestation $(\mathrm{y}=$ $\left.-0.3234 \mathrm{x}^{3}+14.227 \mathrm{x}^{2}-197.88 \mathrm{x}+2600.2 ; \mathrm{R}^{2}=0.46 ; \mathrm{p}<0.05\right)$. Similarly to this study, Debortoli (2009) pointed out a decreasing tendency in rainfall from the 1970s in Colíder $(-6,064)$ and in some municipalities in northern Mato Grosso, including Alta Floresta $(-7,262)$ and Itaúba $(-10,057)$, both surrounding the study region. According to the author, this phenomenon is related to increased deforestation rates in the region, in the opposite direction to that observed in densely forested stations in latitudes of northwest Mato Grosso, which showed an increase in rainfall.
The average of dry and rainy days was 251 and 114 days, respectively. The year 1991 had the highest number of dry days (296 days), while 1996 had the highest number of rainy days (159 days) (Figure 2). In the municipality of Alta Floresta (Mato Grosso), Debortoli (2009) found out that 2007 was the driest year, with 248 dry days, whereas 1992 was the year with the highest number of rainy days (160 days). By comparing data from Alta Floresta and Colíder, which are bordering municipalities, one notices that the driest and rainiest years werenot the same, demonstrating different behaviors in relatively close areas.

Studies carried out by Rosa et al. (2007) revealed that, in a 10-year series, the rainfall behavior in central-western Mato Grosso was quite variable, where the highest rainfall levels $(1,800 \mathrm{~mm}$ to $2,100 \mathrm{~mm})$ occurred in the west, north, and south portions of the study area. It's worthy stressing that the heaviest rains were observed in the area's far west, comprising precisely the regions with denser vegetation cover.

The behavior of the average monthly occurrence of dry and rainy days (Figure 3) showed that the rainy period within this temporal scale was concentrated between October and April, and the driest period was concentrated between June and August. The months presenting the highest number of rainy days were January and March, with 18 rainy days each. In turn, the month showing fewer rainy days was July, with an average of 0.5 days.

According to Ferreira (2001), Colíder presents a dry period lasting three months, from June to August, something which was explicitly observed in this study. This behavior is also observed in other municipalities of Mato Grosso, such as Cáceres (Pizzato et al. 2012) and Tangará da Serra (Dallacort et al. 2011).

The rainfall levels observed during the 28 years (19832011) presented the $\beta$ parameter values of GPDF with variations

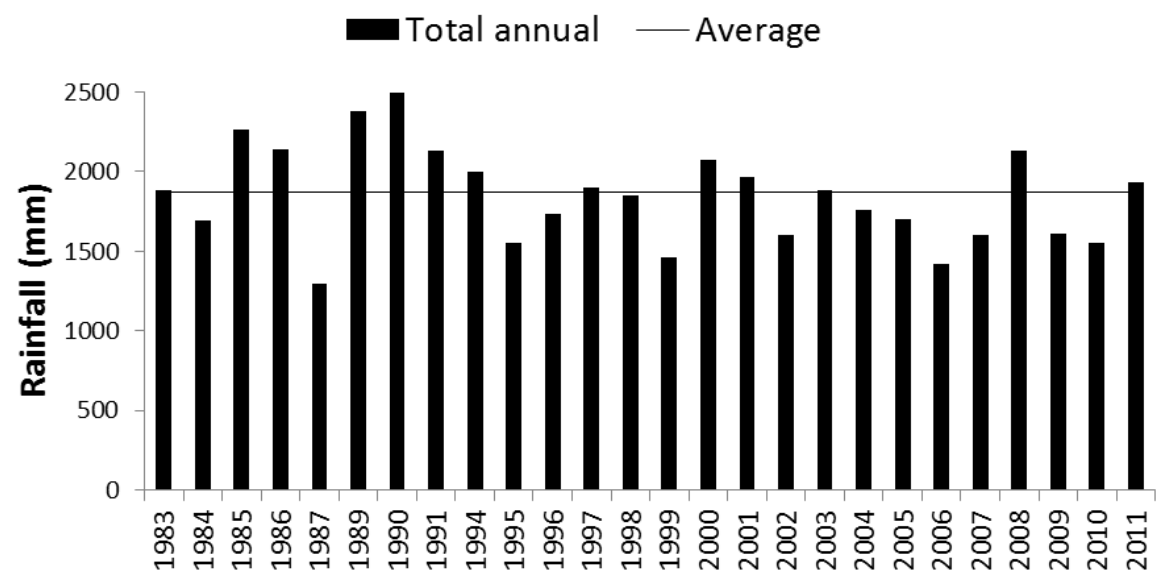

Figure 1 - Annual rainfall distribution in the municipality of Colíder, Mato Grosso, Brazil, within the period from 1983 to 2011. 


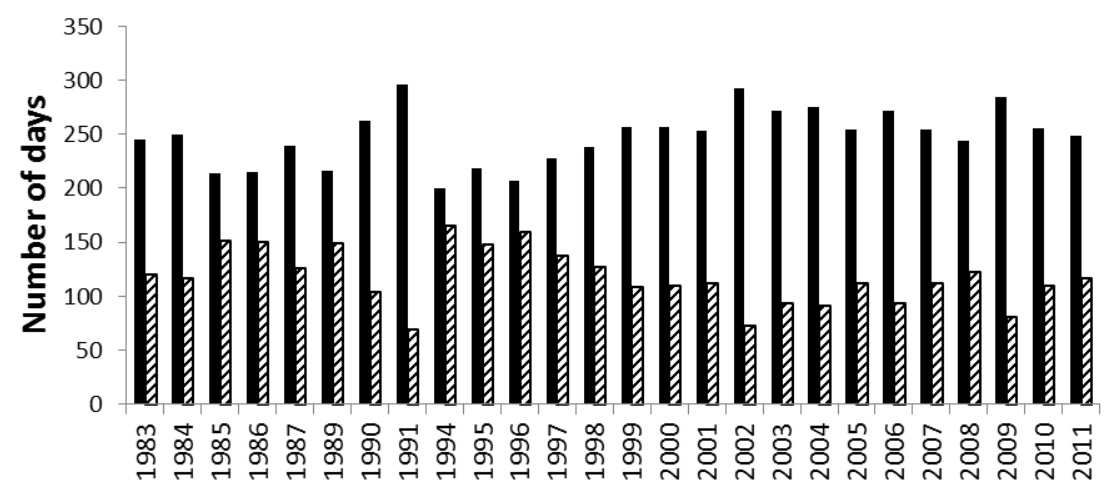

Figure 2 - Annual occurrence of dry and rainy days in the municipality of Colíder, Mato Grosso, Brazil, within the period from 1983 to 2011.

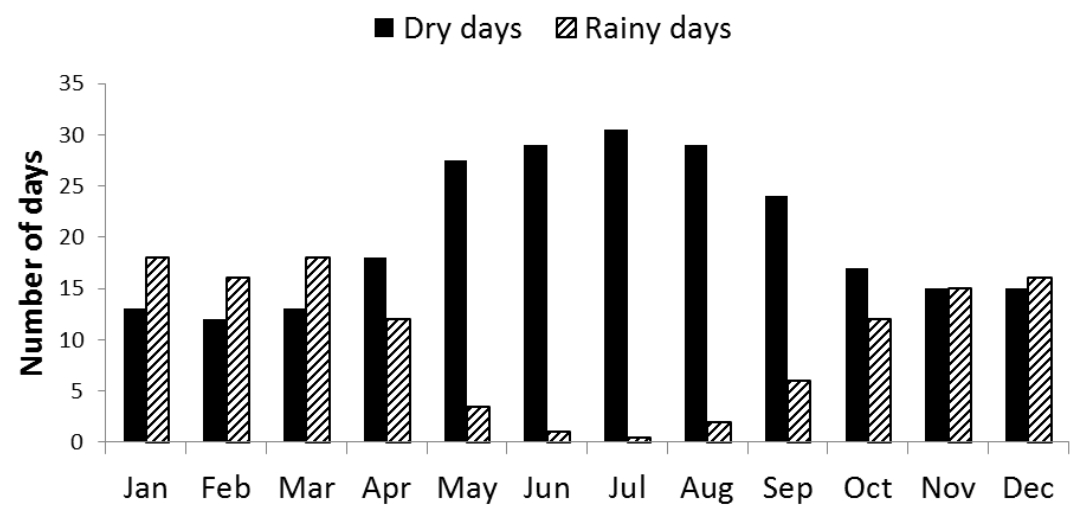

Figure 3 - Monthly average occurrence of dry and rainy days in the municipality of Colíder, Mato Grosso, Brazil, within the period from 1983 to 2011.

of 17.96 in June and 74.89 in December, not exceeding 100, and the $\alpha$ parameter of this function presented minimum values of 0.17 in July and maximum of 6.61 in February (Figure 4), thus the $\alpha$ values are lower than the $\beta$ values.

The highest $\beta$ parameter value was found in December and January; the latter was the month presenting the most intense rainfall averages $(320.79 \mathrm{~mm})$ and the larger standard deviation $(145.24 \mathrm{~mm})$, indicating a greater variability in rainfall. The lowest values coincided with the months of lower rainfall volume in June and July, $5.56 \mathrm{~mm}$ and $8.19 \mathrm{~mm}$, respectively (Table 1).

The scenarios observed through GPDF corroborate several studies carried out in the state of Mato Grosso, such as those by Martins et al.(2010), Moreira et al. (2010), Fietz et al. (2011b) and Pizzato et al.(2012), where this model presented an adequate adjustment, being widely used for determining the probable rainfall.

According to Furlan (2009), probability function adjustment studies using theoretical functions with regard to a set of climatic data have brought benefits to the planning of human activities related to the most varied sectors of society such as economy, environment, and, especially, agriculture and livestock.

Taking into account the cumulative totals of deforested area in the Amazon of Mato Grosso, a gradual increase in deforestation becomes quite evident within the period from 1989 to 2005 (13.17\% p.y.), attenuating up to 2008 (2.75\% p.y.), with a tendency to stabilize from this year on $(0.86 \%$ p.y.) (Figure 5$)$.

One found out, by determining Spearman's $\rho$ coefficient, that there's a negative correlation $(\rho=-0.45)$ between the regional deforestation data and the local rainfall rates. The test showed that the larger the deforested regional area (Amazon of Mato Grosso), the lower the rainfall rate observed by restricting the data analysis only to the decade in which the deforestation rate in Colíder reached a value about 80\% (1989-1999), the test revealed a strong negative correlation between the variables $(\rho=$ -0.84) (Figure 6), demonstrating that the removal of vegetation cover implies a significant decrease in rainfall (Figure 7).

Regarding local data (the municipality of Colíder), cumulative total deforestation values presented a progressive 

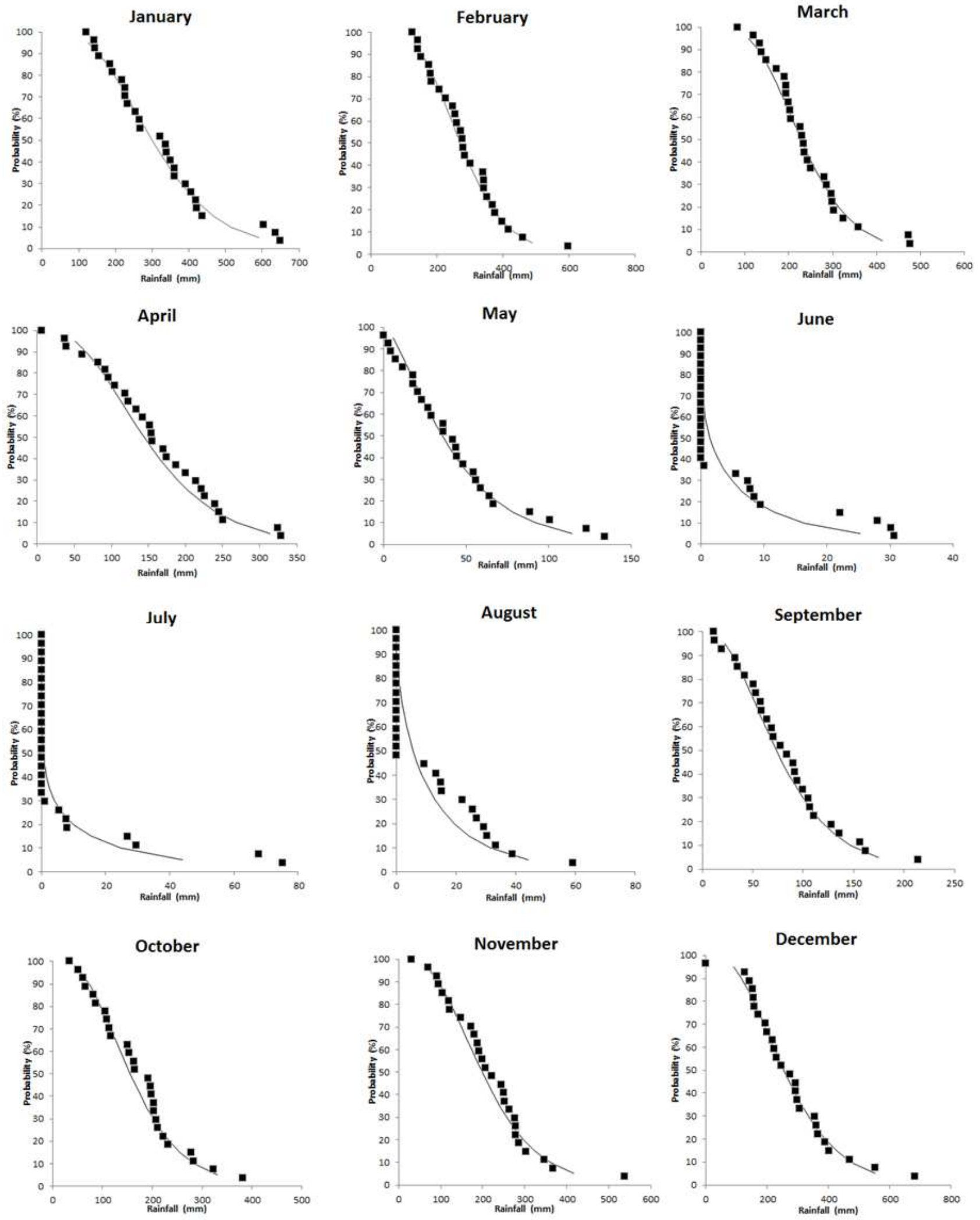

— calculated probability - observed probability

Figure 4. Distribution of calculated and observed probabilities of monthly rainfall in the municipality of Colíder, Mato Grosso, Brazil. 
Table 1 - Values concerning average, standard deviation, and alpha $(\alpha)$ and beta $(\beta)$ parameters of the gamma distribution for 28 years of rainfall data in the municipality of Colíder, Mato Grosso, Brazil.

\begin{tabular}{lrrrrrrrrrrrr}
\hline & Jan & Feb & Mar & Apr & May & Jun & Jul & Aug & Sep & Oct & Nov & Dec \\
\cline { 2 - 11 } Average & 320,79 & 284,51 & 240,5 & 158,44 & 44,52 & 5,56 & 8,19 & 11,83 & 82,7 & 170,07 & 215,93 & 279,90 \\
S.deviation & 145,24 & 110,64 & 94,39 & 82,34 & 35,57 & 9,99 & 19,78 & 16,11 & 48,26 & 86,06 & 107,47 & 144,78 \\
Alpha $\alpha$ & 4,87 & 6,61 & 6,49 & 3,7 & 1,56 & 0,30 & 0,17 & 0,53 & 2,93 & 3,90 & 4,03 & 3,73 \\
Beta $\beta$ & 65,76 & 43,02 & 37,05 & 42,79 & 28,41 & 17,96 & 47,74 & 21,95 & 28,17 & 43,55 & 53,49 & 74,89
\end{tabular}

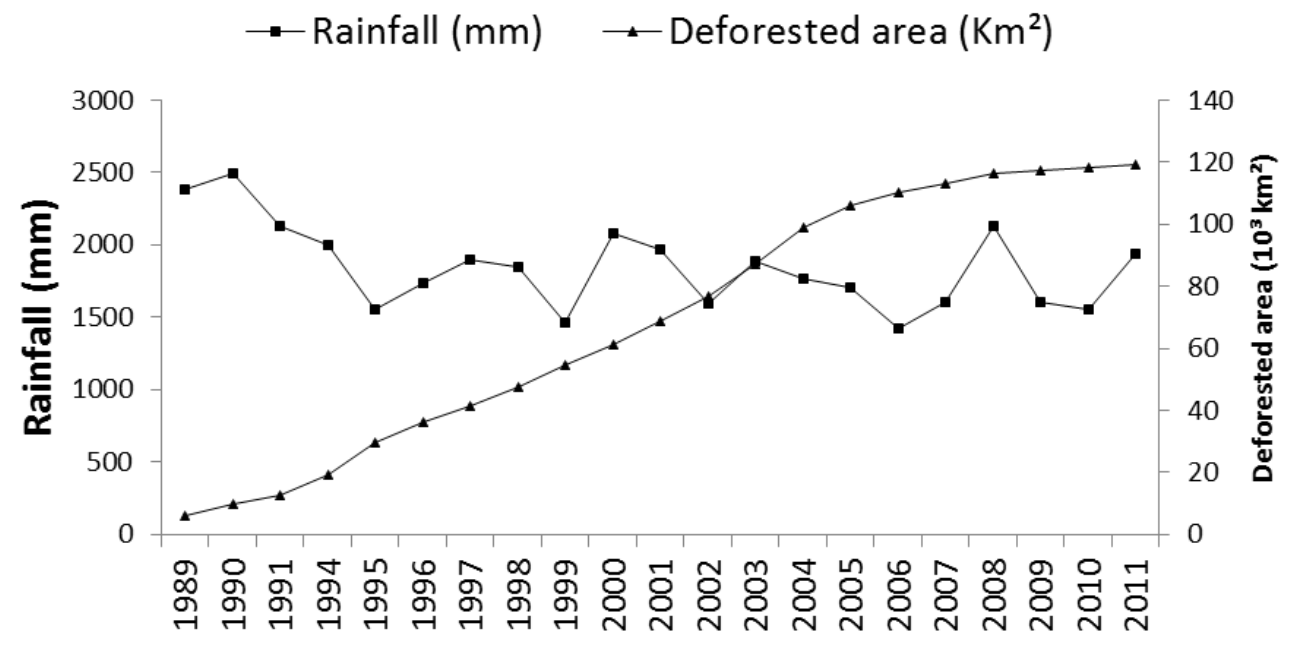

Figure 5 - Cumulative total deforested area in the Amazon of Mato Grosso and rainfall rates in the municipality of Colíder, Mato Grosso, Brazil, within the period from 1988 to 2011.

increase in the rates within the periods from 2000 and 2005 (0.54\% p.y.) and from 2007 to 2008 (0.28\% p.y.), with a considerable stabilization between 2005 and 2007 (0.11\% p.y.) and between 2008 and 2011 ( $0.05 \%$ p.y.). These oscillations are related to historical, political, economic, and social factors. It's worth stressing that these local indexes, when compared to the regional rates, are extremely low, since the municipality had reached 78\% of deforested area in 1999 (INPE, 2011b). After calculating Spearman's $\rho$ coefficient, one found out that there's a negative correlation $(\rho=-0.26)$ between the local deforestation data and the local rainfall rates, as well as what was observed between the regional and local deforestation rates and the local rainfall indexes.

The behaviors observed in Spearman's coefficient are regarded as having medium to high intensity, something which demonstrates a probable association between cause and effect, since the literature points out many similar situations in various deforested tropical regions (Garcia-Carreras and Parker, 2011; Lee and Berbery, 2012; Spracklen et al. 2012). However, evidence of an association between deforestation and rainfall are not always entirely clear in the literature, since the large-scale conversion of forest into pastures and crops is a relatively recent phenomenon in the history of the Amazon Basin.

Early studies on climate changes in the Amazon illustrate a slight tendency of increase in convection and rainfall, especially in the western Amazon Basin, and a small decrease in the meridional Amazon, but the tendency is not significant every year (Chu et al. 1994). This occurs because studies based on the climatic consequences in deforested regions of the Amazon are scarce, in addition to the absence of sufficiently long temporal measurement series (in situ and by satellite), as well as the low density observation network, a fact which justifies this kind of problem (Debortoli, 2009).

However, Marengo (2004) found out that the tendency observed in the rainfall group observed in the series from 1950 to 1998 , showing a decrease in rainfall across the Amazon Basin, with a particularly significant decrease in the north and a positive tendency in the south. As deforestation is more prominent in the southern part of the Amazon, it seems that the connections between deforestation and climate changes in this region weren't fully understood, yet. However, the Amazon Rainforest's role in 


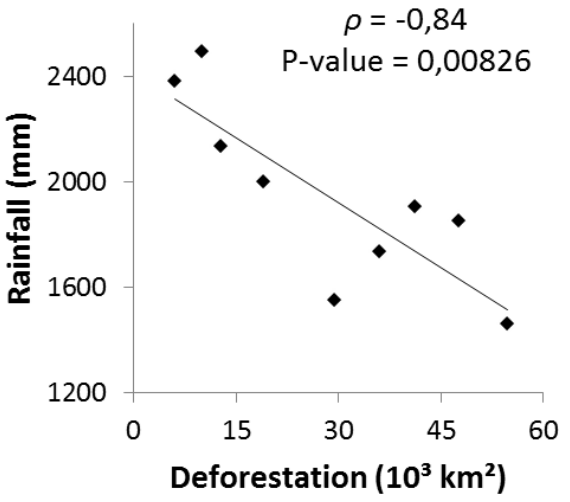

Figure 6 - Spearman's coefficient for the variables rainfall and deforestation $(\rho=-0.84)$ during the decade from 1989 to 1999 in the municipality of Colíder, Mato Grosso, Brazil.

the hydrological cycle and its importance for the maintenance of regional and local climate have become increasingly clear (see Aragão et al. 2012).

According to Sheil and Murdiyarso (2009), forest covers have a key role in atmospheric circulation and water cycling in the continents. Makarieva et al. (2009), for instance, show that continental rainfall in areas without vegetation cover tend to an accelerated decrease as they distance themselves from coastal regions, while forested areas show no decrease in the rainfall rates within the continent.

As a large part of the solar energy used by biota is dissipated through transpiration, it's expected that this process is crucial in the atmospheric moisture recharge performed by forests, since an excessive evapotranspiration of the single layer/ level of the ocean surface potentiate the evaporation strength derived from forests. This leads to the displacement of moisture from the oceans to the forested land areas, a phenomenon responsible for the formation of rainfall in these regions. Thus, vegetation removal can have serious implications for the hydrological cycle (Makarieva and Gorshkov, 2007).

The relationship between vegetation and climate can be quite significant, as noted by Paiva and Clarke (1997), SoaresFilho et al. (2005), Barros (2006), Fearnside (2006), Cohen et al. (2007) and Cordeiro et al. (2008). In this case, the Amazon is an important area and generating scattering of air masses influencing other regions. Therefore, the impacts caused by deforestation may have reflected direct and/or indirect effects on the precipitation regimes at different spatial scales, resulting in changes in bioclimate, microclimate and mesoclima (Debortoli, 2009).

Christofoletti (1995) reports that the hydrological cycle is changed by deforestation,immediately leading to changes in local and regional weather patterns. Similarly, researches with general circulation models of the atmosphere indicate that large-scale deforestation produces changes in the regional climate (Snyder, 2010; Moraes et al. 2013), causing variations in temperature, precipitation, and $\mathrm{CO}_{2}$ emissions. Meso-scale studies demonstrate that local deforestation changes the border layer structure of atmospheric condensation, inducing the formation of secondary circulations and changes inhaziness (Durieux et al. 2003; Wang et al. 2009). As a consequence of these conditions the correlations between factors of different scalar levels may explain the influence of the macro-regional deforestation on the rainfall behavior of macro-regions. Therefore, there may be an actual cause and effect relation in this study, rather than just a possible coincidence in the progressive decrease in rainfall over the two decades studied.

\section{CONCLUSIONS}

1. The GPDF function was adequate to represent monthly rainfall with regard to the probability distribution calculated and observed.

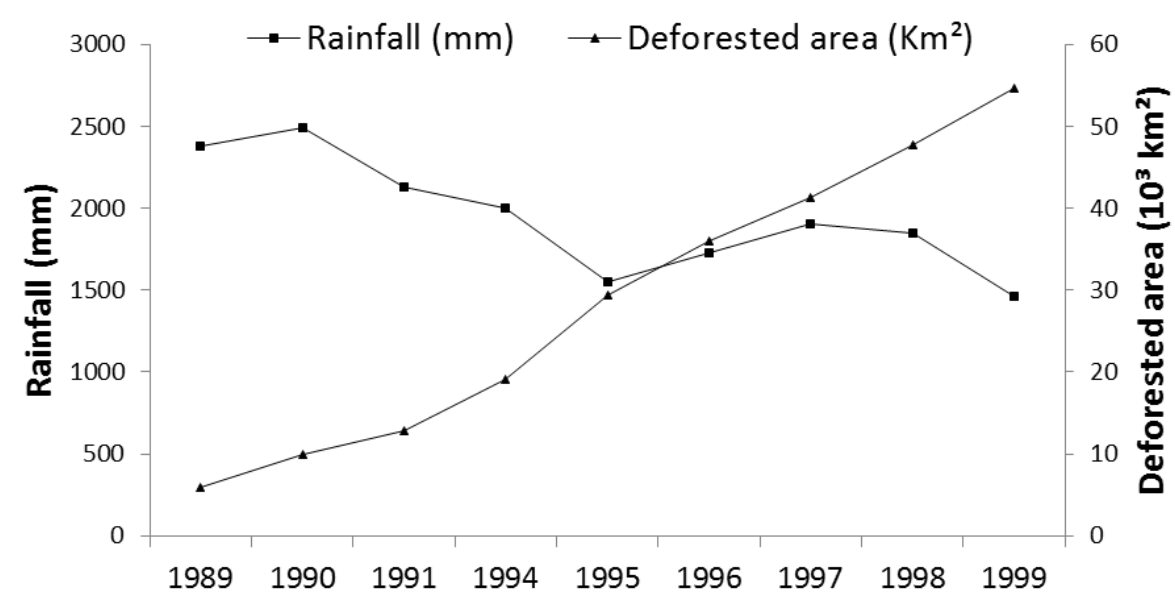

Figure 7 - Cumulative total deforested area and rainfall rates in the municipality of Colíder, Mato Grosso, Brazil, within the period from 1989 to 1999. 
2. The regional deforestation within the study period was very intense and it had a progressive increase in the first 16 years, tending to stabilize from 2008 on.

3. Spearman's coefficient revealed significant negative correlations between the regional and local deforestation levels with local precipitation, showing that the higher the deforested area, the lower the rainfall rate.

4. Gradual decreases in rainfall due to deforestation, whether at macro-scales or meso-scales, can influence the hydrological cycle in tropical regions, such as Colíder, southern Amazon.

5. Further studies are needed in order to check if decrease in rainfall could cause water stress both for forests and agronomic crops, a fact which can affect the whole social, environmental, and economic dynamics in the Amazonian municipalities, specially along the arc of deforestation.

\section{ACKNOWLEDGEMENTS}

The authors thank to the Coordination for the Improvement of Higher Education Personnel (CAPES) and the Foundation for Research Support of the State of Mato Grosso (FAPEMAT) for the MS scholarship granted to the second author and to the National Council of Technological and Scientific Development (CNPq) for the research productivity scholarship granted to the third and fourth authors and for the financial support to the Project CNPq/PPBio 457602/2012-0 coordinated by BH Marimon-Junior.

\section{REFERENCES}

ARAGÃO, L. E. O. C.; MALHI, Y.; BARBIER, N.; LIMA, A.; SHIMABUKURO, Y.; ANDERSON, L.; SAATCHI, S. Interactions between rainfall, deforestation and fires during recent years in the Brazilian Amazonia. Philosophical Transactions of the Royal Society B, London, v. 363, n. 1498, p. 1779-1785, 2012.

ASSIS, F. N.; ARRUDA, H. V.; PEREIRA, A. R. Aplicações de estatística à climatologia: teoria e prática. 1ed. Pelotas: Universidade Federal de Pelotas, 161p., 1996.

BARIOU, R.; MORENO, G.; MAITELLI, G. T. Colonisation agricola et peuplement en Amazonie matogrossense. In: DUBREUIL, V. Environnement et Télédétection au Brésil. Université Rennes, Haute Bretagne, 198 p., 2002.

BARROS, F. A. Efeito de borda em fragmento de floresta montana, Nova Friburgo, RJ, 2006. 100f. Dissertação (Mestrado em Ciência Ambiental), Universidade Federal Fluminense.

BUCKERIDGE, M. S. Mudanças climáticas, biodiversidade e sociedade: como a teoria de redes pode ajudar a compreender o presente e planejar o futuro? Revista Multiciência, Campinas, n. 8, p. 88-107, 2007.

BUCKERIDGE, M. S. Biologia e Mudanças Climáticas no Brasil. São Carlos: RiMa, 316p., 2008.

CHRISTOFOLETTI, A. Geografia física nos estudos das mudanças climáticas. In: BECKER, B. K. Geografia e Meio Ambiente no Brasil. São Paulo: Hucitec, p. 334-345, 1995. CHU, P. S.; YU, Z. P. E.; HASTENRATH, S. Detecting Climate Concurrent with Deforestation in the Amazon Basin: Which Way Has It Gone? Bulletin of the American Meteorological Society, Boston, v.75, p. 579-83, 1994.

COHEN, J. C. P.; BELTRÃO, J. C.; GANDU, A. W.; SILVA, R. R. Influência do desmatamento sobre ciclo hidrológico da Amazônia. Ciência e Cultura, Campinas, v. 59, n. 3, p. 36-39, 2007.

CORDEIRO, S. A.; SOUZA, C. C.; MENDOZA, Z. M. S. H. Florestas brasileiras e as mudanças climáticas. Revista Cientifica Eletrônica de Engenharia Florestal, Garça, v. 11, p. 1-20, 2008.

CORREA, M. G. G.; GALVANI, E. Uma abordagem teórica das interações no Sistema Superfície-Atmosfera (SSA) na bacia do Rio Piquiri - PR. Revista Geonorte, Manaus, v. 1, n. 5, Edição Especial 2., p. 1245-1255, 2012.

COSTA, A. O.; SALGADO, C. M.; DINALI, Y. T. Caracterização da precipitação no médio vale do Rio Paraíba do Sul Fluminense (RJ). Revista Geonorte, Manaus, v. 2, n. 5, Edição Especial 2., p. 1000-1013, 2012.

DALLACORT, R.; MARTINS, J. A.; INOUE, M. H.; FREITAS, P. S. L.; COLETTI, A. J. Distribuição das chuvas no município de Tangará da Serra, médio norte do Estado de Mato Grosso, Brasil. Acta Scientiarum Agronomy, Maringá, v. 33, n. 2, p. 193-200, 2011.

DEBORTOLI, N. S. O ciclo hidrológico no norte do estado do Mato Grosso e sua relação com o uso do solo em uma perspectiva temporal (1977-2007): Adaptabilidade e vulnerabilidade populacional frente às mudanças climáticas regionais. 2009. 137f. Dissertação (Mestrado em Desenvolvimento Sustentável) - Universidade de Brasília.

DELIRE, C.; NOBLET-DUCOUDRÉ, N.; SIMA, A.; GOUIRAND, I. Vegetation Dynamics Enhancing Long-Term Climate Variability Confirmed by Two Models. Journal of Climate, Boston, v.24, n. 9, p. 2238-2257, 2011.

DURIEUX, L.; MACHADO, L.A.T.; LAURENT, H. The impact of deforestation on cloud cover over the Amazon arc of deforestation. Remote Sensing of Environment, v. 86, p. 132-140, 2003.

ESTATCAMP. Action. Versão 2.4. Licença Pública geral. São Carlos, 1991. Disponível em: < http://www.portalaction. com.br >. Acesso em: 05 jan. 2013. 
FARID, L.H.; MACHADO, J. E. B.; GONZAGA, M. P.; PEREIRA FILHO, S. R.; CAMPOS, A. E. F.; FERREIRA, N. S.; SILVA, G. D.; TOSAR, C. R.; CAMARA, V.; HACON, S. S.; LIMA, D.; SILVA, V.; PEDROSO, L. R. M.; CASTRO e SILVA, E.; MENEZES, L. A. Preliminary diagnosis of the environmental impacts caused by gold prospecting in Alta Floresta - MT: a case study. Rio de Janeiro: CETEM/CNPq, 190p., 1992.

FEARNSIDE, P. M. Desmatamento na Amazônia: dinâmica, impactos e controle. Acta Amazonica, Manaus, v. 36, n. 3, p. 395-400, 2006.

FERREIRA, J. C. V. Mato Grosso e seus municípios. 19 ed. Cuiabá: Secretaria de Estado de Educação 660p., 2001.

FIETZ, C.R.; COMUNELLO, E.; CREMON, C.; DALLACORT, R. Probabilidade de Ocorrência de Períodos sem Chuva no Estado de Mato Grosso.Dourados: Embrapa Agropecuária Oeste, 95p., $2011 \mathrm{a}$.

FIETZ,C.R.; COMUNELLO, E.; CREMON, C.; DALLACORT, R.; PEREIRA, S. B. Chuvas Intensas no Estado de Mato Grosso. 2ed. Dourados: Embrapa Agropecuária Oeste, 117 p., 2011 b.

FURLAN, D. N. Variabilidade temporal e espacial das chuvas e do balanço hídrico no estado de Rondônia: caracterização e analise de tendência. 2009. 129f. Dissertação (Mestrado em Agronomia). ESALQ - Universidade de São Paulo.

GARCIA-CARRERAS, L.; PARKER, D. J. How does local tropical deforestation affect rainfall? Geophysical Research Letters, Irvine, v. 38, L19802, 2011.

GUIMARÃES, E. N.; LEME, H. J. Caracterização histórica e configuração espacial da estrutura produtiva do CentroOeste. In HOGAN, D. J. et al. Migração e meio ambiente no Centro-Oeste. Núcleo e Estudos de População Universidade Estadual de Campinas, Campinas, 42p, 2002.

INPE - Instituto Nacional de Pesquisas Espaciais. Banco de Dados Meteorológicos. 2011a. Disponível em: <http:// bancodedados.cptec.inpe.br/> Acesso em: 05 nov. 2013.

INPE - Instituto Nacional de Pesquisas Espaciais. Projeto de

Estimativa do Desflorestamento da Amazônia. 2011b. Disponível em: <http://www.obt.inpe.br/prodes/index.php> Acesso em: 11 nov. 2012.

LAPOLA, D. M.; SCHALDACH, R.; ALCAMO, J. BONDEAU, A.; MSANGI, S.; PRIESS, J. A.; SILVESTRINI, R.; SOARES-FILHO, B. S. Impacts of Climate Change and the End of Deforestation on Land Use in the Brazilian Legal Amazon. Earth Interactions, Boston, v. 15, n. 16, p. 1-29, 2011.

LEE, S.; BERBERY, E. H. Land Cover Change Effects on the Climate of the La Plata Basin. Journal of Hydrometeorology, Washington,v. 13, n. 1, p. 84-102, 2012.
LEWIS, S. L.; BRANDO, P. M.; PHILLIPS, O. L.; VAN DER HEIJDEN, G. M. F.; NEPSTAD, D. The 2010 Amazon Drought. Science, New York, v. 331, n. 6017, p. 554, 2011.

LIBERATO, A. M.; BRITO, J. I. B. Influência de mudanças climáticas no balanço hídrico da Amazônia Ocidental. Revista Brasileira de Geografia Física, Recife, v. 3, n. 3, p. 170-180, 2010.

MAKARIEVA, A. M.; GORSHKOV, V. G. Biotic pump of atmospheric moisture as driver of the hydrological cycle on land. Hydrology and Earth System Sciences, Munich, v. 11, p. 1013-1033, 2007.

MAKARIEVA, A. M.; GORSHKOV V. G.; Li, B. Precipitation on land versus distance from the ocean: Evidence for a Forest pump of atmospheric moisture. Ecological Complexity, v. 6, p. 302-307, 2009.

MARCUZZO, F. F. N.; ROCHA, H. M.; MELO, D. C. R. Mapeamento da precipitação pluviométrica no bioma da Amazônia do estado do Mato Grosso. In: SIMPÓSIO DE RECURSOS HÍDRICOS DO NORDESTE, 10, 2010, Fortaleza. Anais...Fortaleza: ABRH, 2010.

MARENGO, J. Interdecadal variability and trends of rainfall across the Amazon basin. Theoretical and Applied Climatology, Vienna, v. 78, p. 79-96, 2004.

MARTINS, J. A.; DALLACORT, R.; INOUE, M. H.; SANTI, A.; KOLLING, E. M.; COLETTI, A. J. Probabilidade de precipitação para a microrregião de Tangará da Serra, Estado do Mato Grosso. Pesquisa Agropecuária Tropical, Goiânia, v. 40, n. 3, p. 291-296, 2010.

MORAES, E. C.; FRANCHITO, S. H.; RAO, V. B. Amazonian Deforestation: Impact of Global Warming on the Energy Balance and Climate. Journal of Applied Meteorology and Climatology, Boston, v. 52, n.3, p. 521-530, 2013.

MOREIRA, P. S. P.; DALLACORT, R.; AGALHÃES, R. A.; INOUE, M. H.; STIELER, M. C.; SILVA, D. J.; MARTINS, J. A. Distribuição e probabilidade de ocorrência das chuvas no município de Nova Maringá-MT. Revista de Ciências Agroambientais, Alta Floresta, v. 8, n. 1, p. 9-20, 2010.

NEGRI, A. J.; ADLER, R. F.; XU, L.; SURRATT, J. The Impact of Amazonian Deforestation on Dry Season Rainfall. Journal of Climate, Boston, v. 17, p. 1306-1319, 2004.

PAIVA, E. M. C. D.; CLARKE, R. T. Relações de recorrência da precipitação na Amazônia. Revista Brasileira de Recursos Hídricos, Porto Alegre, v. 2, n. 2, p. 173-189, 1997.

PIZZATO J.A.; DALLACORT, R.; TIEPPO, R. C.; MODOLO, A. J.; CREMON, C.; MOREIRA, P. S. P. Distribuição e probabilidade de ocorrência de precipitação em Cáceres (MT). Pesquisa Agropecuária Tropical, Goiânia, v. 42, n. 2, p. 137-142, 2012. 
REYDON, B. P. O desmatamento da floresta amazônica: causas e soluções. Política Ambiental, Belo Horizonte, v. 1, n. 8, p. 143-155, 2011.

ROSA, D. B.; SOUZA, R. R.; NASCIMENTO, L.A.; TOLEDO, L. G.; TOPANOTTI, D. Q.; NASCIMENTO, J. A. A distribuição espacial das chuvas na porção centro-oeste do Estado de Mato Grosso - Brasil. Revista Eletrônica da Associação dos Geógrafos Brasileiros, Três Lagoas, v. 1 n. 5, p. 127-152, 2007.

SELUCHINESK, R. D. C. De heróis a vilões: Imagem e autoimagem dos colonos da Amazônia mato-grossense. 2008. 263f. Tese (Doutorado em Desenvolvimento Sustentável) - Universidade de Brasília.

SHEIL, D.; MURDIYARSO, D. How forests attract rain: An examination of a new hypothesis. BioScience, Washington, v. 59, n. 4, p. 341-347, 2009.

SNYDER, P. K. The Influence of Tropical Deforestation on the Northern Hemisphere Climate by Atmospheric Teleconnections. Earth Interactions, Boston, v. 14, n. 4, p. 1-34, 2010.

SOARES-FILHO, B. S..; NEPSTAD, D. C.; CURRAN, L. M. CERQUEIRA, G. C.; GARCIA, R. A.; RAMOS, C. A.; VOLL, E.; MCDONALD, A.; LEFEBVRE, P.; SCHLESINGER, P.; MCGRATH, D. Cenários de desmatamento para a Amazônia. Estudos Avançados, São Paulo, v. 19, n. 54, p. 138-152, 2005.
SOUSA, R. R.; ROSA, D. B.; NASCIMENTO, L. A.; LIMA, P. R. M. Estudo da variabilidade pluviométrica no extremo norte do Estado de Mato Grosso entre os anos de 1990 a 1996. Revista Geoambiente On-Line, Jataí, v. 1, n. 7, p. 89-107, 2006.

SOUZA, S. C. Desmatamento e clima em Alta Floresta - Amazônia mato-grossense. 2006. 92f. Dissertação (Mestrado em Geografia) - Universidade Federal de Mato Grosso.

SPRACKLEN, D. V.; ARNOLD, S. R.; TAYLOR, C. M. Observations of increased tropical rainfall preceded by air passage over forests. Nature, London, v. 489, p. 282-285, 2012.

THOM, H. C. S. A note on the gama distribution. Monthly Weather Review, Boston, v. 86, p. 117-122, 1958.

WANG, J.; CHAGNON, F. J. F.; WILLIAMS, E. R.; BETTS, A. K.; RENNO, N. O.; MACHADO, L. A. T.; BISHT, G.; KNOX, R.; BRAS, R. L. Impact of deforestation in the Amazon basin on cloud climatology. Proceedings of the National Academy of Sciences of the United States of America, Washington, v. 106, n. 10, p. 3670-3674, 2009.

ZAR, J. H. Biostatistical analysis. 4 ed. New Jersey: PrenticeHall, Inc., 663p., 1999. 